\title{
INDISPENSABLE IMMIGRANTS
}

THE WINE PORTERS OF NORTHERN ITALY AND THEIR SAINT, 1200-1800

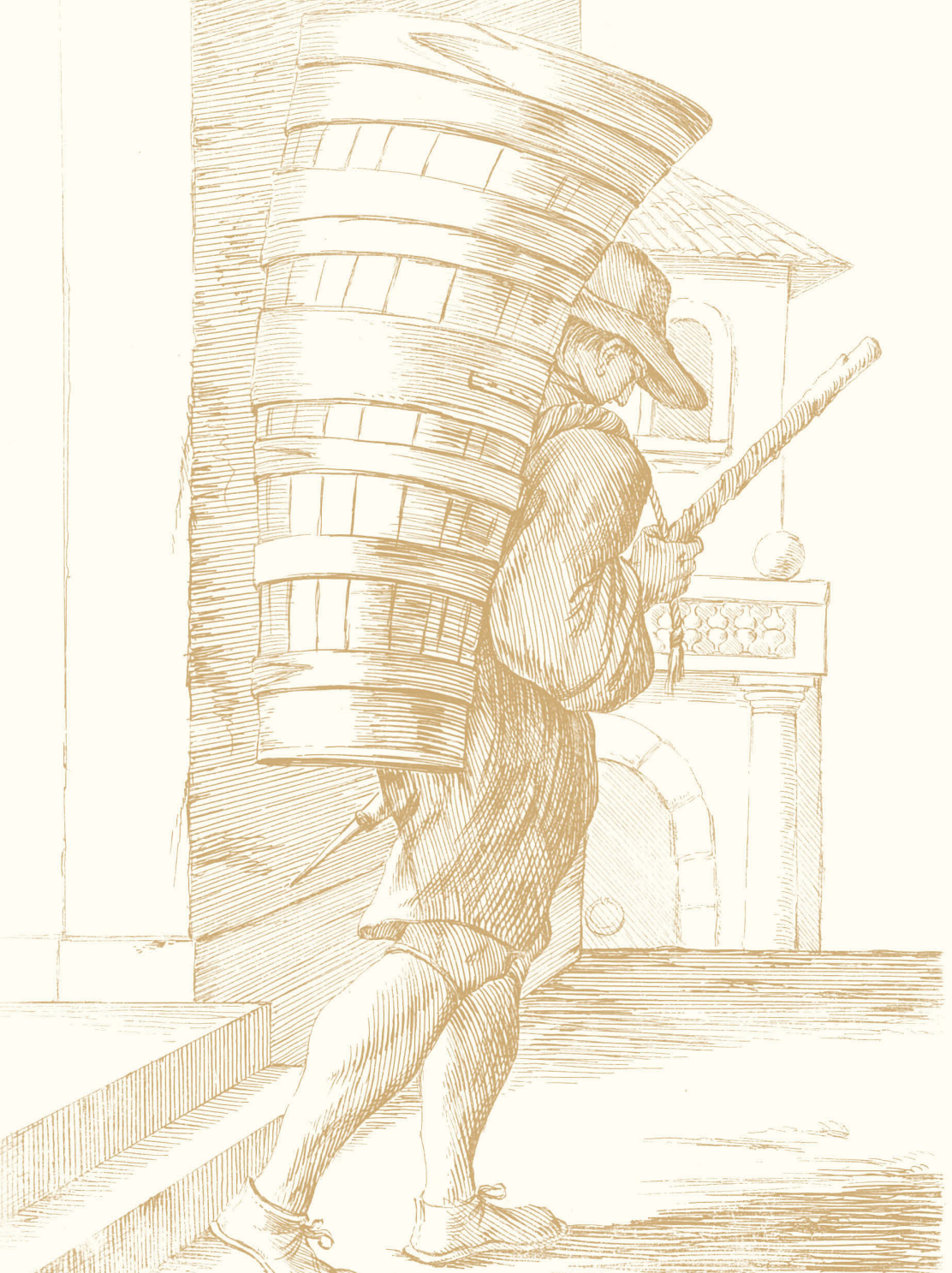

LESTER K: LITTLE 
Lester K. Little - 9781526101761

Downloaded from manchesterhive.com at 04/26/2023 08:32:17AM 


\section{Indispensable immigrants}

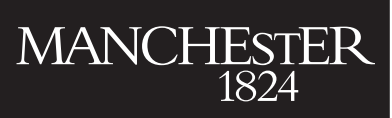

Manchester University Press 
Lester K. Little - 9781526101761

Downloaded from manchesterhive.com at 04/26/2023 08:32:17AM 


\section{Indispensable immigrants}

The wine porters of northern Italy and their saint, 1200-1800

\section{Lester K. Little}

Manchester University Press

Manchester and New York 
Copyright (C) Lester K. Little 2014

The right of Lester K. Little to be identified as the author of this work has been asserted by him in accordance with the Copyright, Designs, and Patents Act 1988.

Published by Manchester University Press

Oxford Road, Manchester M13 9NR, UK

and Room 400, 175 Fifth Avenue, New York, NY 10010, USA

www.manchesteruniversitypress.co.uk

Distributed in the United States exclusively by

Palgrave Macmillan, 175 Fifth Avenue, New York,

NY 10010, USA

Distributed in Canada exclusively by

UBC Press, University of British Columbia, 2029 West Mall,

Vancouver, BC, Canada V6T 1 Z2

British Library Cataloguing-in-Publication Data

A catalogue record for this book is available from the British Library

Library of Congress Cataloguing-in-Publication Data applied for

ISBN 9780719095221 hardback

First published 2014

The publisher has no responsibility for the persistence or accuracy of URLs for any external or third-party internet websites referred to in this book, and does not guarantee that any content on such websites is, or will remain, accurate or appropriate.

Typeset

by Out of House Publishing 